\title{
Peningkatan Kemampuan Internet of Things Bagi Guru TKJ di SMK Walisongo Semarang
}

\author{
Alauddin Maulana Hirzan ${ }^{1}$, Whisnumurti Adhiwibowo ${ }^{2}$, April Firman Daru ${ }^{3}$ \\ ${ }^{1,2,3}$ Fakultas Teknologi Informasi dan Komunikasi, Universitas Semarang \\ E-mail: ${ }^{1}$ maulanahirzan@usm.ac.id, ${ }^{2}$ whisnu@usm.ac.id, ${ }^{3}$ firman@usm.ac.id
}

\begin{abstract}
Abstrak
Teknologi Internet of Things merupakan sebuah teknologi yang memungkinkan perangkat untuk berkomunikasi satu sama lainnya. Dengan mengimplementasikan teknologi ini, dapat meningkatkan efisiensi serta produktivitas kinerja dunia industri. Karena itulah banyak industri yang menginginkan lulusan yang siap kerja dan memiliki pemahaman mengenai teknologi Internet of Things ini. Untuk mendapatkan lulusan yang sesuai dengan kebutuhan industri ini, para siswa dan guru di SMK Walisongo perlu memiliki pemahaman mengenai teknologi ini. Namun para guru SMK ini belum pernah mendapatkan pelatihan mengenai teknologi ini. Sehingga diperlukanlah pelatihan untuk meningkatkan kemampuan para guru dalam menguasai Internet of Things. Pelatihan ini dilaksanakan selama dua hari dengan durasi yang telah ditentukan. Dari pelatihan yang telah dilakukan, para peserta mengalami peningkatan pemahaman hingga 33,83\% dibandingkan sebelum pelatihan diberikan. Oleh karena itu, bisa disimpulkan bahwa pelatihan yang dilakukan ini telah meningkatkan kemampuan para guru sehingga lebih siap untuk menghasilkan lulusan yang sesuai dengan kebutuhan industri.
\end{abstract}

Kata kunci: Internet of Things, Jaringan Komputer, SMK Walisongo Semarang,

\begin{abstract}
Internet of Things is a technology that enabled communication between machine-tomachine either wired or wireless. By implementing this technology, the industry can increase its productivity and efficiency significantly. Because of these advantages, many industries tried to hire graduate students that ready to work and have Internet of Things-related skills. To fulfill the industry needs, all the students and teachers in Walisongo Vocational School must meet the requirements. However, the teachers in this vocational school did not have a proper curriculum to cover the Internet of Things. Hence, IoT-related skills and understanding training is required to improve teachers' knowledge. This training is conducted for two days with a determined duration. According to the training result, the knowledge of the participants was increased up to $33.83 \%$ better than before training. Thus, it can be concluded that the training can increase the teachers' Internet of Things-related skills to fulfill the industry's needs.
\end{abstract}

Keywords: Internet of Things, Computer Network, Walisongo Semarang Vocational School

\section{PENDAHULUAN}

Perkembangan jaringan komputer yang semakin baru menghadirkan sebuah teknologi yang memungkinkan perangkat-perangkat biasa untuk berkomunikasi satu sama lain melalui jaringan yang ada ini disebut dengan Internet of Things[1]. Teknologi Internet of Things (IoT) ini dapat dimanfaatkan untuk berbagai macam sektor, khususnya untuk sektor industri yang biasanya memproduksi barang maupun jasa. Industri memerlukan teknologi ini untuk meningkatkan bagi dari segi produktivitas maupun efektifitas[2][3]. Dengan meningkatkan efektifitas pekerja, industri dapat melakukan penghematan anggaran[4]. Selain itu dengan meningkatnya produktivitas, industri dapat meningkatkan profit yang didapatkan dari produksi 
yang dilakukan. Sehingga bisa dipastikan teknologi ini dapat meningkatkan keuntungan industri di berbagai aspek. Untuk memenuhi kebutuhan ini, industri mengambil lulusan-lulusan SMK yang siap bekerja dan memiliki keahlian yang lebih pasti.

SMK Walisongo Semarang merupakan salah satu sekolah vokasional yang menghasilkan lulusan-lulusan untuk memenuhi kebutuhan tenaga kerja industri. Namun ada beberapa permasalahan yang harus dihadapi oleh SMK Walisongo untuk bisa menghadirkan lulusan-lulusan ini. Di SMK ini sendiri kurikulum mengenai Internet of Things belum banyak dihadirkan ke sekolah, sehingga baik para guru maupun siswanya belum memiliki pemahaman mengenai Internet of Things ini. Pemahaman yang dimaksudkan di sini adalah, pemahaman mengenai konsep, konfigurasi fisik, maupun perbaikan masalah yang bisa jadi terjadi.

Pelatihan-pelatihan mengenai Internet of Things telah banyak dilakukan di berbagai SMK maupun SMA di Indonesia. Pelatihan yang dilakukan mengajarkan bagaimana melakukan konfigurasi perangkat maupun untuk meningkatkan soft skill para siswa. Di tahun 2018 pelatihan Internet of Things yang diberikan untuk siswa di SMAN 5 Tegal berhasil menaikkan pemahaman para siswa untuk penerapan sehari-hari[5]. Kegiatan pelatihan yang juga dilaksanakan di tahun yang sama di Madrassah Darussa'adah dengan mengangkat teknologi Internet of Things ini berhasil meningkatan pemahaman lebih lanjut dari teknologi ini[6]. Pelatihan lebih spesifik ke perangkat Internet of Things yang dilaksanakan di sebuah SMK di bekasi ini menghasilkan siswa-siswa yang memiliki pemahaman mengenai perakitan perangkat beserta konfigurasi khusus untuk perangkat ESP8266[7]. Pelatihan lain yang memanfaatkan teknologi Arduino juga pernah dilaksanakan di SMK Karya Utama. Dari pelatihan yang dilaksanakan ini, para siswa berhasil mendesain teknologi Internet of Things dengan otomatisasi Android[8].

Dari pelatihan-pelatihan yang telah dilakukan sebelumnya ini menjadi inspirasi untuk menghadirkan pelatihan Internet of Things untuk SMK Walisongo Semarang. Pelatihan yang dilaksanakan ini membahas lebih lanjut konsep dan konfigurasi komunikasi untuk perangkat Internet of Things. Sehingga pelatihan yang dilakukan ini diharapkan dapat memberikan pemahaman serta kemampuan yang sesuai dengan kebutuhan industri

\section{METODE}

Untuk menyelesaikan masalah yang dihadapi oleh mitra, pengabdian kepada masyarakat yang dilaksanakan ini menggunakan metode ceramah, diskusi, praktik dan asistensi langsung yang dilaksanakan dalam waktu dua hari dengan durasi yang telah ditentukan[3]. Berikut ini adalah alur pelatihan berdasarkan waktu pelaksanaannya:

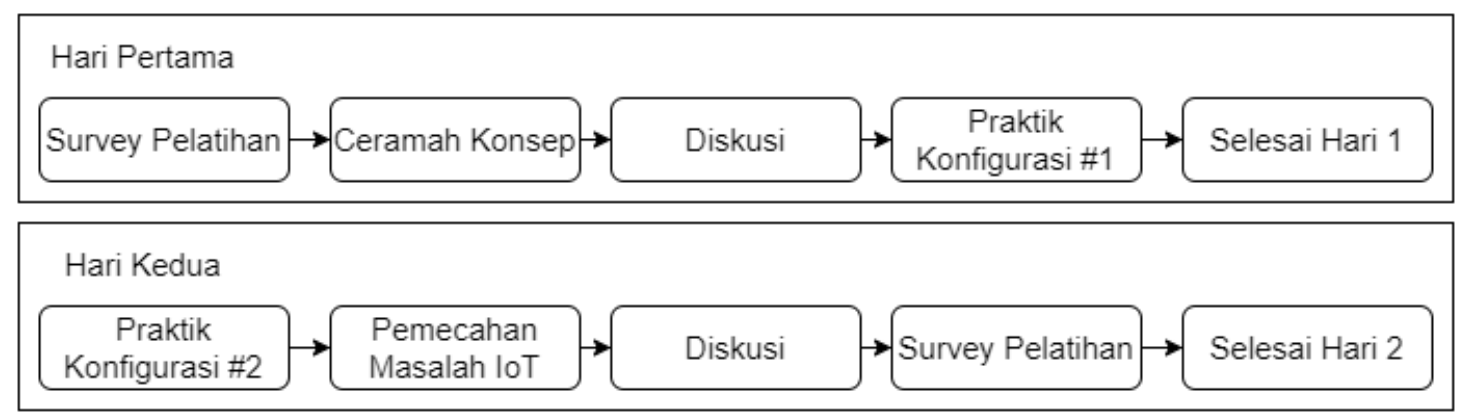

Gambar 1. Tahapan Pelatihan Internet of Things

Kegiatan pelatihan yang dilaksanakan sesuai dengan protokol kesehatan dan pembatasan kerumunan. Pelatihan ini dimulai dan diakhiri dengan survey sebagai bentuk umpan balik, evaluasi kemampuan yang dimiliki oleh para peserta. Proses survei dilakukan dengan menggunakan media daring untuk mempermudah proses kalkulasinya nanti. Survey yang diberikan kepada para peserta ini berisikan materi-materi konsep, konfigurasi, dan pemecahan 
masalah Internet of Things. Sehingga bisa dijadikan indikator pemahaman para peserta yang lebih spesifik dan detail.

Ketika survey sudah diisi oleh para peserta, kegiatan dilanjutkan dengan ceramah konsep komunikasi Internet of Things. Materi yang dihadirkan di sini berupa slide persentasi mengenai teknik komunikasi dengan perangkat Internet of Things. Diskusi dilakukan untuk memberikan kesempatan para peserta untuk bertanya jawab terhadap materi yang diberikan.

Untuk memudahkan pemahaman atas materi yang diberikan, pengabdian ini memberikan kesempatan untuk para peserta mempraktikan langsung konfigurasi komunikasi perangkat. Proses praktikum ini disertai dengan asistensi oleh tim sehingga dapat membantu pemberian materi yang dilakukan. Dikarenakan waktu yang terbatas pelatihan dilanjutkan di hari kedua. Di hari selanjutnya, tim melanjutkan praktikum dan materi pemecahan masalah IoT. Di tahap ini peserta kembali diberi kesempatan untuk diskusi karena masalah IoT cukup banyak dan luas.

Kegiatan pengabdian ini kemudian dievaluasi untuk mengidentifikasikan pemahaman yang dirasakan oleh para peserta sebelum dan sesudah pelatihan dilaksanakan. Untuk memperjelas penilaian survey, pertanyaan dibagi menjadi tiga kategori dengan pecahan nilai yang berbeda sebagai berikut:

Tabel 1. Komposisi Survei dan Nilai

\begin{tabular}{|c|l|c|}
\hline No & \multicolumn{1}{|c|}{ Komposisi } & Nilai Maksimal \\
\hline 1 & Konseptual & $30 \%$ \\
\hline 2 & Konfigurasi & $50 \%$ \\
\hline 3 & Pemecahan Masalah & $20 \%$ \\
\hline
\end{tabular}

Tabel komposisi ini akan dijadikan indikator evaluasi pemahaman para peserta baik sebelum dan sesudah pelatihan diberikan. Komposisi nilai Konseptual adalah 30\%, sedang Konfigurasi 50\% serta Pemecahan Masalah 20\%. Nilai konfigurasi memiliki komposisi tertinggi dikarenakan pemahaman praktik adalah utama dibandingkan teori saja.

\section{HASIL DAN PEMBAHASAN}

Hasil survei yang diambil diawal kegiatan pengabdian ini merupakan indikator pemahaman awal para peserta mengenai teknologi Internet of Things. Di tahap pra-pelatihan ini menghasilkan tabel dengan sampel data sebagai berikut:

Tabel 2. Sampel Hasil Survei Pra-Pelatihan

\begin{tabular}{|c|c|c|c|c|c|c|c|c|c|c|c|c|}
\hline No & Inisial & Q1 & Q2 & Q3 & Q4 & Q5 & Q6 & Q7 & Q8 & Q9 & Q10 & Total \\
\hline 1 & AAA & 1 & 1 & 0 & 1 & 0 & 0 & 1 & 1 & 1 & 1 & 7 \\
\hline 2 & SK & 1 & 1 & 1 & 0 & 0 & 0 & 1 & 1 & 1 & 1 & 7 \\
\hline 3 & GL & 0 & 1 & 0 & 0 & 1 & 0 & 0 & 1 & 1 & 1 & 5 \\
\hline 4 & SK & 0 & 1 & 0 & 1 & 1 & 1 & 1 & 1 & 0 & 0 & 6 \\
\hline 5 & AM & 1 & 0 & 1 & 0 & 0 & 1 & 1 & 0 & 1 & 0 & 5 \\
\hline
\end{tabular}

Untuk menjaga privasi data peserta, survei yang dilakukan hanya menggunakan inisial nama saja. Setiap pertanyaan yang diajukan di survei dinilai dengan 1 poin dengan total 10 poin. Kemudian data ini diolah untuk mendapatkan pemahaman awal para peserta mengenai materi yang diberikan. Pertanyaan-pertanyaan mencakup materi Konsep (pertanyaan satu sampai tiga), Konfigurasi (pertanyaan 4 sampai delapan), dan Pemecahan Masalah (pertanyaan sembilan dan sepuluih). Hasil dari data ini kemudian dikalkulasikan dengan bobot masing-masing kategori. Berikut ini adalah hasil perhitungan survei awal sebelum pelatihan diberikan: 


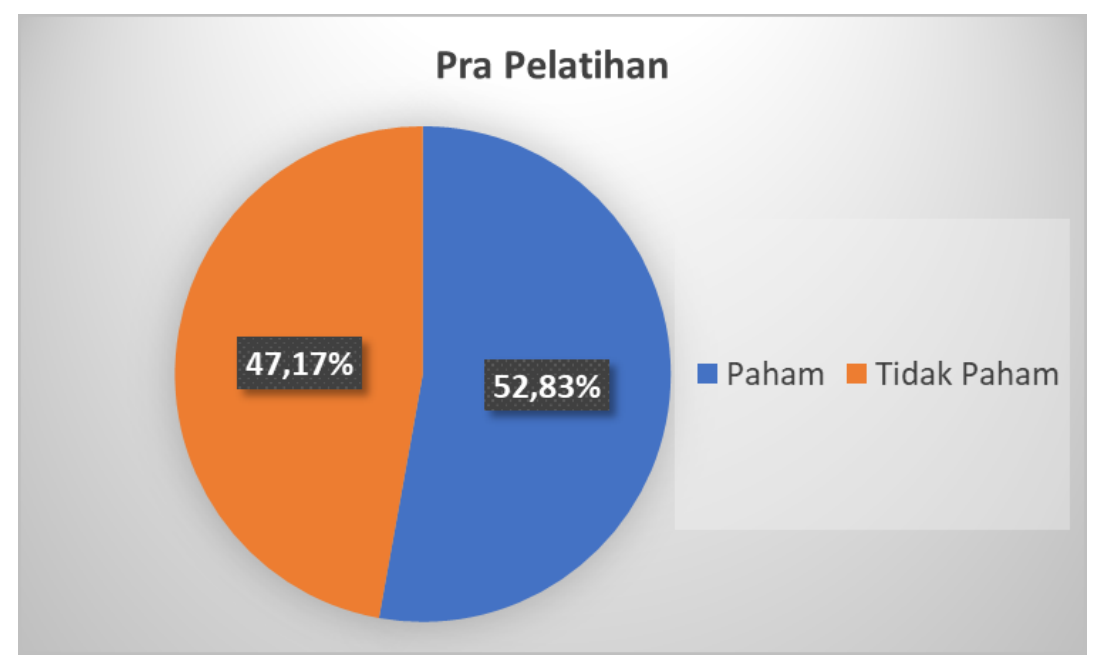

Gambar 1. Hasil Survei Pra-Pelatihan

Dari survey pra-pelatihan yang dilakukan, pemahaman para peserta mengenai teknologi IoT mencapai $52,83 \%$. 47,17\% dari materi belum dipahami dengan baik. Berikut ini adalah rincian pemahaman para peserta berdasarkan kategori pertanyaannya:

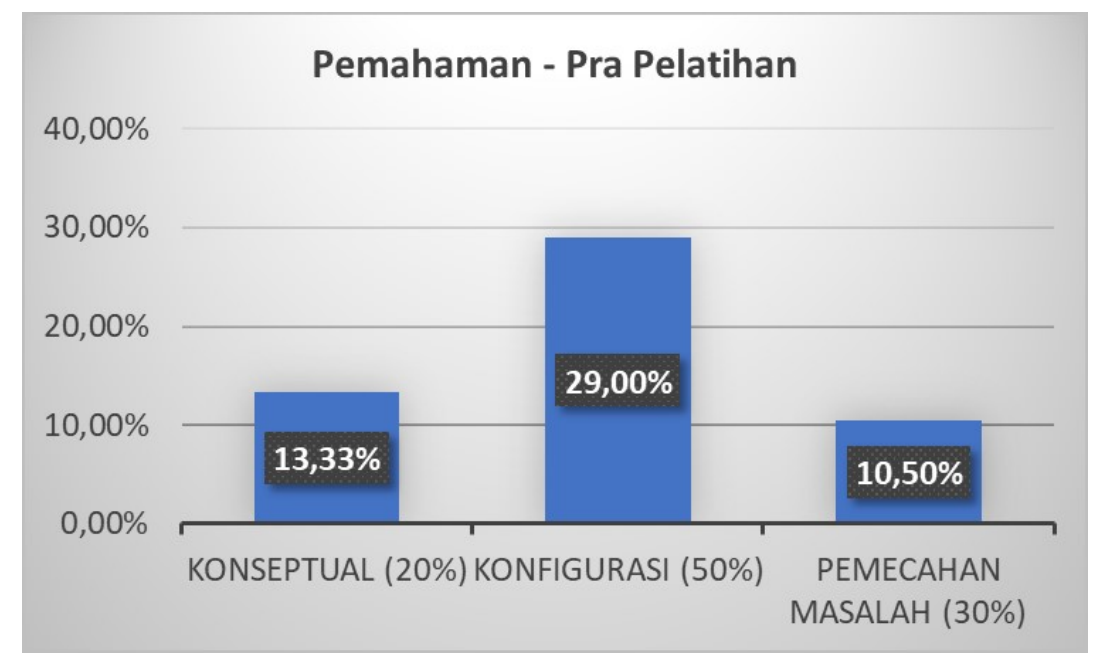

Gambar 2. Rincian Survei Pra-Pelatihan

Persentase 52,83\% yang didapatkan dari survei pra-pelatihan memiliki rincian sebagai berikut: 1) Pemahaman konseptual mencapai $13,33 \%$ dari $20 \%$,2) pemahaman konfigurasi mencapai $29 \%$ dari $50 \%$, dan 3) pemecahan masalah mencapai $10,50 \%$ dari $30 \%$. Dari data yang dihadirkan ini, bisa diketahui bahwa para guru SMK belum memiliki pemahaman serta kemampuan yang cukup mengenai teknologi IoT.

Evaluasi terakhir yang dilakukan setelah pelatihan berakhir adalah survei paskapelatihan yang di mana para peserta mengisi kembali formulir daring yang telah diberikan sebelumnya. Sampel data hasil dari survei paska pelatihan adalah sebagai berikut:

Tabel 3. Sampel Data Survei Paska-Pelatihan

\begin{tabular}{|c|c|c|c|c|c|c|c|c|c|c|c|}
\hline No & Nama & Q1 & Q2 & Q3 & Q4 & Q5 & Q6 & Q7 & Q8 & Q9 & Q10 \\
\hline 1 & AAA & 1 & 1 & 1 & 1 & 1 & 1 & 1 & 1 & 1 & 1 \\
\hline 2 & SK & 1 & 1 & 1 & 0 & 0 & 0 & 1 & 1 & 1 & 1 \\
\hline
\end{tabular}




\begin{tabular}{|l|l|l|l|l|l|l|l|l|l|l|l|}
\hline 3 & GL & 1 & 1 & 1 & 1 & 1 & 0 & 1 & 1 & 1 & 1 \\
\hline 4 & SK & 0 & 1 & 1 & 1 & 1 & 1 & 1 & 1 & 1 & 1 \\
\hline 5 & AM & 1 & 1 & 1 & 1 & 0 & 1 & 1 & 0 & 1 & 1 \\
\hline
\end{tabular}

Jika dibandingkan dengan sampel data sebelumnya, terjadi peningkatan jawaban benar dari para peserta setelah kegiatan dilaksanakan. Sebagai bentuk refleksi dari data sampel paskapelatihan, berikut adalah grafis survei paska pelatihan:

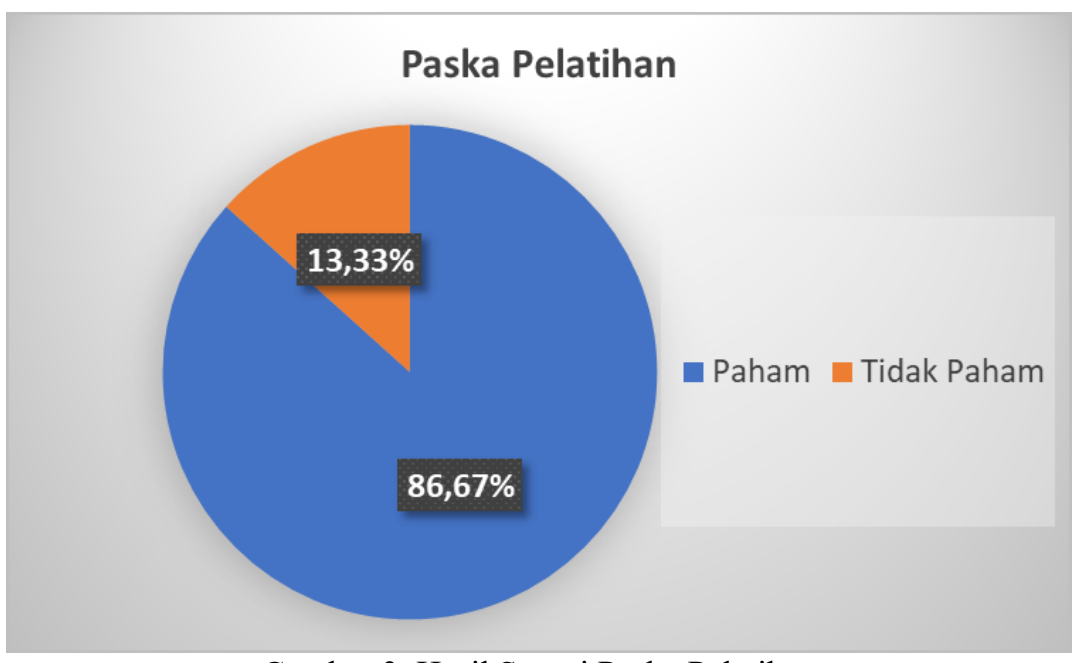

Gambar 3. Hasil Survei Paska Pelatihan

Terjadi peningkatan mencapai 33,83\% pemahaman yang didapatkan oleh para peserta pelatihan. Peserta dapat memahami materi yang diberikan lebih baik dari sebelum pelatihan diberikan. Berikut ini adalah rincian pemahaman berdasarkan survei yang dilakukan:

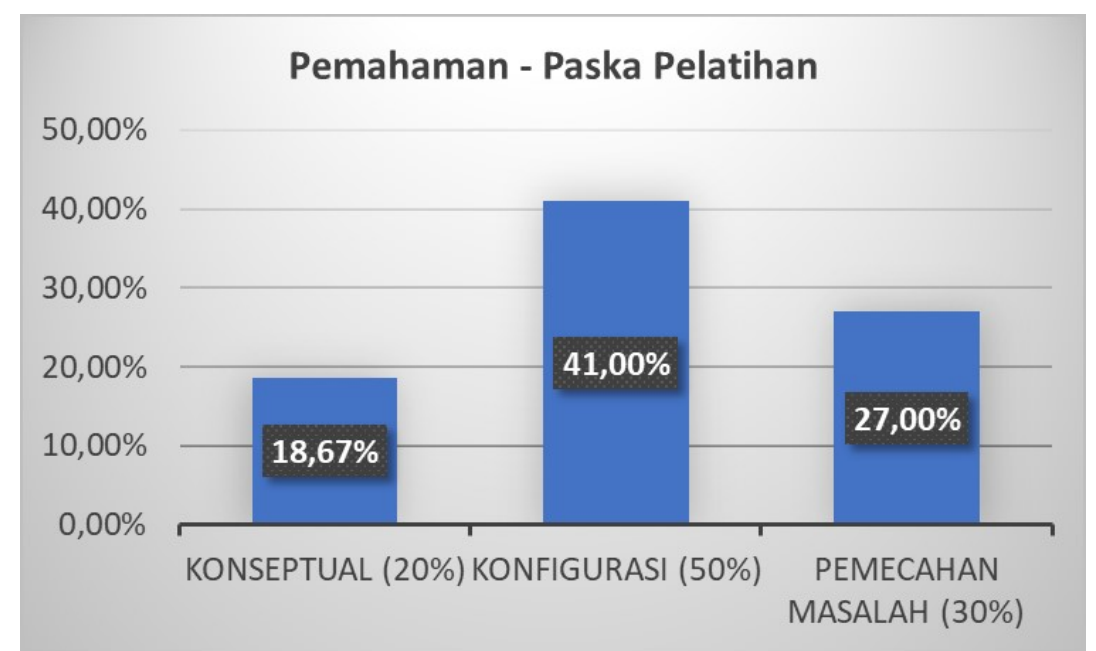

Gambar 4. Rincian Survei Paska-Pelatihan

Jika dilihat dari masing-masing kandungan materi yang diberikan saat survei, terjadi kenaikan nilai pemahaman dibandingkan rincian sebelumnya. Dan dari semua kategori pertanyaan, semua mendekati nilai maksimum masing-masing. Berikut adalah tabel kesimpulan hasil perbandingan survei pra dan paska pelatihan. 
Abdimasku, Vol. 4, No. 3, September 2021: 278-284

Tabel 4. Perbandingan Survei Pra dan Paska Pelatihan

\begin{tabular}{|c|c|c|c|}
\hline & Pra & Paska & Perbedaan \\
\hline Konseptual (20\%) & $13,33 \%$ & $18,67 \%$ & $5 \%$ \\
\hline Konfigurasi (50\%) & $29,00 \%$ & $41,00 \%$ & $12 \%$ \\
\hline Pemecahan Masalah (30\%) & $10,50 \%$ & $27,00 \%$ & $17 \%$ \\
\hline Total & $52,83 \%$ & $86,67 \%$ & $33,83 \%$ \\
\hline
\end{tabular}

Terdapat kenaikan yang cukup baik di masing-masing kategori pernyataan, yang di mana terjadi kenaikan sebesar 5\% untuk Konseptual, 12\% untuk Konfigurasi, dan 17\% untuk Pemecahan Masalah. Dengan total kenaikan pemahaman para peserta yang mencapai 33,83\%, bisa disimpulkan bahwa pelatihan yang diberikan sukses meningkatkan kemampuan serta pemahaman peserta mengenai teknologi IoT.

\section{KESIMPULAN DAN SARAN}

SMK Walisongo adalah Sekolah kejuruan yang memiliki tujuan untuk menghasilkan lulusan-lulusan yang siap bekerja di dunia kerja maupun industri. Namun dengan munculnya kebutuhan baru dunia industri akan lulusan yang memiliki pemahaman serta kemampuan dalam bidang Internet of Things, memunculkan masalah baru untuk SMK Walisongo. Guru maupun siswa SMK Walisongo belum memiliki pemahaman maupun kemampuan yang memadai untuk memenuhi kebutuhan industri ini.

Untuk menyelesaikan masalah ini, kegiatan pengabdian kepada masyarakat dilakukan untuk memberikan pelatihan untuk para guru di SMK Walisongo. Pelatihan yang dilakukan selama dua hari dengan durasi yang telah ditentukan ini mengajarkan Konsep, Konfigurasi dan Pemecahan Masalah pada teknologi Internet of Things. Pelatihan yang dilakukan ini menggunakan metode ceramah, diskusi, dan praktik dengan asistensi untuk mempercepat proses pemahaman materi kepada para peserta. Sebagai bahan evaluasi dari pelatihan yang dilakukan, kegiatan ini memberikan survei yang dikerjakan sebelum dan sesudah pelatihan yang diberikan. Survei sebelum pelatihan dilakukan menghasilkan nilai 52,83\%, ini membuktikan kurangnya pemahaman IoT para peserta. Setelah pelatihan dilakukan, para peserta mengalami peningkatan pemahaman mencapai $86,67 \%$. Dengan perbedaan $33,83 \%$ ini menjadi bukti bahwa pelatihan yang diberikan ini telah sukses meningkatkan pemahaman serta menyelesaikan permasalaha mitra.

\section{UCAPAN TERIMA KASIH (JIKA ADA)}

Kami mengucapkan terima kasih kepada Lembaga Penelitian dan Pengabdian Kepada Masyarakat (LPPM) Universitas Semarang karena telah memberikan dukungan material serta moriil bagi tim pengabdian.

\section{DAFTAR PUSTAKA}

[1] D. Serpanos and M. Wolf, Internet-of-things (IoT) systems: Architectures, algorithms, methodologies. Springer, 2017.

[2] M. S. Balaji and S. K. Roy, "Value co-creation with Internet of things technology in the retail industry," J. Mark. Manag., vol. 33, no. 1-2, pp. 7-31, Jan. 2017, doi: 10.1080/0267257X.2016.1217914.

[3] G. Lampropoulos, K. Siakas, and T. Anastasiadis, "INTERNET OF THINGS IN THE CONTEXT OF INDUSTRY 4.0: AN OVERVIEW," Int. J. Entrep. Knowl., vol. 7, no. 1, pp. 4-19, Jun. 2019, doi: 10.37335/ijek.v7i1.84.

[4] "INDUSTRY 4.O : The combination of the Internet of Things (IoT) and the Internet of 
People (IoP)." https://web.b.ebscohost.com/abstract?direct=true\&profile=ehost\&scope=site\&authtype= crawler\&jrnl=09739785\&AN=135923168\&h=wJ8pYhGzP2471\%2BcxjDSKo\%2F2Msj 2le9EEJ8K5RvtITtko6IJeZCVjMd2ocRj5hulb6Ho6TlT7\%2FU31vUlh66wrUw\%3D\%3 D\&crl $=c \&$ resultNs $=$ AdminWebAuth\&resultLo (accessed Apr. 15, 2021).

[5] I. Afriliana, E. Budihartono, and Y. Sabanise, "PENGENALAN INTERNET OF THINGS (IOT) UNTUK PENINGKATAN SOFTSKILL PADA SISWA SMA N 5 TEGAL," J. Pengabdi. Masy. Progresif Humanis Brainstorming, vol. 1, no. 2, pp. 9297, Jul. 2018, doi: 10.30591/japhb.v1i2.953.

[6] H. S. Setiawan, "Pelatihan Guru dalam Penggunaan Internet of Things pada Madrasah Darussa'adah," E-Dimas J. Pengabdi. Kpd. Masy., vol. 9, no. 2, p. 167, 2018, doi: 10.26877/e-dimas.v9i2.1554.

[7] M. Manfaluthy and R. Ekawati, "Pelatihan Internet of Things (IoT Trainer) Berbasis ESP8266 pada SMK Al-Muhadjirin Bekasi," Pros. Semin. Nas. Pengabdi. Masy. LPPM $U M J$, no. September, 2019.

[8] R. Ananda and M. Amin, "Workshop Pelatihan Perancangan Internet of Things Berbasis Arduino Uno Jenis R3/R3 Smd Di Smk Swasta Karya Utama Kota Tanjungbalai," Jurdimas (Jurnal Pengabdi. Kpd. Masyarakat) R., vol. 2, no. 2, pp. 121-126, 2019, doi: 10.33330/jurdimas.v2i2.371. 